\title{
A Mandatory Uniform Policy in Urban Schools: Findings from the School Survey on Crime and Safety: 2003-04
}

\author{
SEUNGHEE HAN \\ University of Missouri
}

\begin{abstract}
The main purpose of the study is to examine the relationships between a mandatory school uniform policy and students' problem behaviors. The study is based on the School Survey on Crime and Safety (SSOCS) 2003-04 data. Analyzing data from 421 urban schools, the study found that schools adopting a mandatory uniform policy are negatively associated with number of students' problem behaviors while the level of schools' safety initiatives are constant. In addition, the study revealed parental involvement at the elementary school level and teacher training and community efforts at the high school level as negative predictors of students' problem behaviors.
\end{abstract}

Han, S. (2010). A Mandatory Uniform Policy in Urban Schools: Findings from the School Survey on Crime and Safety: 2003-04. International Journal of Education Policy and Leadership 5(8). Retrieved [date] from www.ijepl.ca.

\section{Introduction}

Mandatory school uniform policies began to be initiated in the late 1980s across the United States (Brown, 1998), and schools increasingly adopted them in the mid-1990s. In particular, the policies were enacted to reduce gang problems and enhance school security (Zernike, 2002). Many school practitioners and parents believe that uniform policies improve student academic achievement, student self-esteem, disciplinary practices, and the overall learning environment (Brown, 1998; U.S. Department of Education, 1996; Pate, 2006; Ryan \& Ryan, 1998). Based on these beliefs, the Clinton and Bush administrations encouraged schools to implement uniform policies (Boutelle, 2008; Zernike, 2002). However, opponents of mandatory uniform policies argue that they violate students' First Amendment rights, which include the freedom of speech and expression, and create an authoritarian atmosphere and system that are not desirable for edu- cating students (Brown, 1998). Critics also say these policies do not improve student academic achievement, behavioral outcomes, or self-esteem; do not promote a better learning environment; and do not minimize class stratification among students (Brunsma, 2006). Additionally, the cost of the uniform may cause financial difficulties for poor families (Portner, 1996).

The debate continues, and opinion and perception about the effect of uniform policies on school safety vary and there are still disagreements among various stakeholders. Although school practitioners, researchers, and policy makers have demanded more empirical studies to see the impact of a mandatory uniform policy (Anderson, 2002), to date, very few empirical studies have been conducted.

The main goal of the current study is to examine whether a mandatory uniform policy is associated with the number of students' problem behaviors. In order to explore the relationships between a mandatory uniform policy and number of students' problem behav-

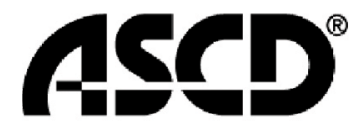

LEARN. TEACH. LEAD.
SIMON FRASER UNIVERSITY THINKING OF THE WORLD

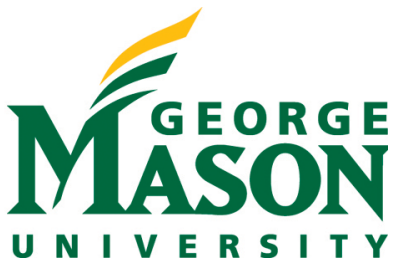


iors, various school safety efforts (e.g., crime prevention programs, community efforts, and teacher training) are also examined simultaneously in the analysis model. In doing so, the findings will provide initial evidence of how a mandatory uniform policy solely relates to the number of students' problem behaviors. Because it is more common for urban schools to implement a mandatory uniform policy and to have more frequent students' problem behaviors than rural schools, the study focuses on urban schools that serve a diverse student population. In addition, number of students' problem behaviors is associated with number of enrolled students; school size is included as a control variable. The samples were obtained from the School Survey on Crime and Safety (SSOCS) 2003-04 data.

\section{Student Problem Behaviors: Fre- quency and Types}

A recent national report (Guerino et al., 2006) showed that most public schools in the United States had violent incidents during the 2003-04 school year. Data from nationally representative samplings of public school principals showed that more than 90 percent of school principals experienced various students' problem behaviors. Students' problem behaviors varied in severity, ranging from minor misbehaviors (such as class disruption) to serious violent behaviors, including rape, physical attack, and robbery. The report provided by school principals shows reliable information in light of school principals' responsibility for being aware of students' problem behaviors. However, students' self-reports should be also considered when it comes to measuring students' problem behaviors (Lawrence, 2007; Thornberry \& Krohn, 2000); principals may not notice all students' behaviors and even principals noticed, they may not report all incidents considering a negative school image to the public (Mellard \& Seybert, 1996).

Students' perspectives were reported in a national study based on the data from adolescents between 9th and 12th grade in the 50 states and the District of Columbia (Center for Disease Control and Prevention, 2006). The survey results from 13,953 students in 159 schools showed the students' misbehaviors by race, gender, and grade. According to the report, a total of 6.5 percent of students reported that they had brought weapons to school, and a total of 7.8 percent of students reported they had been threatened or injured by students with weapons in school more than once during the past 12 months. These incidents occurred more frequently among male students. A total of 13.6percent of students reported that they were involved in physical fights in school more than once during the past 12 months. More than 40 percent (43.4 percent) of students reported that they had used alcohol at least once during the past 30 days; alcohol usage was more frequent among white and Hispanic students and 12th grade students, compared to black students and 9th through 11th grade students. Regarding illegal drug use, 20.2 percent of students reported they had used marijuana more than once during the past 30 days, and 4.5 percent of students reported they had used marijuana in their school. In addition, more than one-fourth of students (25. 4 percent) reported that they had observed the presentation, sale, or possession of an illegal drug in schools.

\section{Problem Behavior and Student Characteristics: Minority Status and Achievement}

Students' problem behaviors have been measured as disciplinary outcomes in the literature, and the positive relationships between minority students and disciplinary outcomes have been well documented (Achilles, McLaughlin, \& Croninger, 2007; Applied Research Center, 2002; Raffaele Mendez et al., 2002; Skiba et al., 2002; Skiba et al., 1997; Thornton \& Trent, 1988).

Several state reports showed a higher level of disciplinary outcomes among minority students. In Tennessee, black students are presented as a higher percent of offenders accounting for total black student population during the 2001-02 through 2004-05 school years. For example, during the 2004-05 school year, 34 percent of total zero-tolerance offenders were black students, which equaled 25 percent of total black student enrollment (Roberto et al., 2006). In Maryland, black and American Indian students are more likely to be suspended, and these disproportional rates have increased from 1995 to 2003 (Krezmien, Leone, \& Achilles, 2006). Similarly, in Indiana, about 40 black students per 100 experienced out-ofschool suspension, compared to 10 white students per 
100 for the 2002-03 school year. In addition, nonwhite students were expelled from school three times more frequently than white students (Rausch \& Skiba, 2004).

On the other hand, in Texas, during the 2005-06 school year, more than 70 percent of disciplinary alternative education programs participants were Hispanic and black students: 48 percent and 25.8 percent, respectively (Texas Education Agency, 2007). In North Carolina, the number of students who were suspended long-term increased by 27 percent between the 2000-01 and 2001-02 school year, and black and multiracial students comprised more than half of the total number of long-term suspensions (Irwin \& Algozzine, 2005).

Researchers have examined the relationship between students' problem behaviors and academic achievement. Analyzing longitudinal data, Arcia (2007) found that students who experienced suspension tend to have lower reading achievement than students who have not. In addition, suspended students' reading scores decreased between the 2001-02 and 2003-04 school years. Similarly, Skiba and Rausch (2004) analyzed data of the Indiana Department of Education and the test scores of the Indiana State Test of Educational Progress (ISTEP) and examined school disciplinary practices by students' characteristics. The researchers found that schools with a higher rate of out-of-school suspension were associated with lower passing rates, compared to the schools with lower rates of out-of-school suspension. Another longitudinal study showed clear predictions of suspended students in regard to achievement. Based on the samples from 584 black male students in 26 middle schools in a large urban school district, Anderson and colleagues (2007) found that, once suspended, students tend to be suspended repeatedly and were mostly lowperforming students. That is, suspended students tend to have experienced suspension in the previous school year, and students who have lower scores in the state standardized reading test were more likely to be suspended in the following school year as well.

\section{The Effects of School Uniform Poli- cies in the Literature}

Many researchers, education practitioners, and policymakers have shown little agreement regarding the advantages and disadvantages of mandatory uniform policies. According to the empirical studies, implementing a uniform policy contributes to improving students' sense of belonging (Fosseen, 2006); developing students' pride in their school (Kim \& Delong, 2006); creating a sound learning environment (Hughes, 2006); decreasing violent incidents and gang problems (Loesch, 1995; Lopez, 2003; White \& Beal, 1999); and reducing discipline outcomes, such as suspension and referrals to juvenile authorities (Draa, 2005; Hughes, 2006; Pate, 2006).

In contrast to such positive advantages, other studies showed that uniform policies have little or negative influence on student outcomes and learning environments; and have no effect on raising attendance rates (Hughes, 2006), decreasing gang presence (Wade $\&$ Stafford, 2003), or creating a positive school climate (Wade \& Stafford, 2003). Furthermore, uniform policies negatively affect the development of positive student self-perception (Wade $\&$ Stafford, 2003) and an increase in academic achievement (Brunsma \& Rockquemore, 1998).

Many empirical studies examined the effect of school uniform policies on students' problem behaviors. Pate (2006), analyzing longitudinal data from 64 elementary schools in one district in Florida between the 1996-97 and 2000-01 school years, found that uniform policies tended to decrease referrals to juvenile authorities and violent behaviors. The results showed that, between pre uniform policy and four years after uniform policy, the average numbers of juvenile referrals and violent incidents were reduced from 1.28 to 0.39 and from 88.04 to 42.06 , respectively.

Another study about the effect of uniform policy also showed a decrease of both students' problem behaviors and discipline outcomes. Conducting a survey of school personnel, parents, and students from two middle schools in Texas during the 1995-96 school year, Hughes (2006) found that a uniform policy did not affect attendance rates but did influence discipline referrals. In addition, the study reported that severe and minor offenses, compared to moderate offenses, decreased significantly after the schools adopted uniform policies.

One of the most expected effects from implementing uniform policies is a reduction in gang problems. Wade and Stafford (2003), conducting a survey of 415 
students and 83 teachers from six middle schools in a metropolitan area, found that schools with uniform policies showed a significant decrease in gang presence as perceived by teachers. The researchers compared the mean differences of responses of students and teachers between schools with and without school uniform policies. Although the study provided good evidence of the positive effect of a uniform policy, one of the limitations is that the researchers collected data from students in grades 6 through 8, but teachers' data were from teachers in kindergarten through 8th grade; thus, the results may have been affected by the variance of the participants' characteristics. In addition, gang problem was measured as perception rather than actual incidents.

Overall, limitations of previous studies on the uniform policies include measurements relying on the participants' perception rather than actual observations and a lack of initial variables in the analysis when they examine the effect of uniform policies as safety purposes (e.g., controlling for other school safety initiatives). In addition, there are widely contrasting opinions among students and school practitioners and parents in terms of support for uniform policies, so previous studies' results may differ based on data obtained from different stakeholders. For example, teachers perceive that uniform policies help create a safer and more orderly learning environment, whereas students do not perceive that the school climate changed (DaCosta, 2006; Hughes, 2006 ; Kim \& Delong, 2006). Most importantly, prior studies paid little attention to other school safety efforts when assessing the effects of uniform policies. This study examined how uniform policies are associated with students' problem behavior and simultaneously considered other school safety initiatives.

Despite a continued debate on school uniform policies, very few empirical studies have concentrated on the effects of uniform policy using nationally representative data. The present study, analyzing national data, seeks to find relationships between students' problem behaviors and uniform policy in diverse urban schools after controlling for various school safety initiatives.

\section{Rationale of the Study}

Although many previous studies have addressed the influence of adopting uniform policies in terms of prevention of students' problem behaviors, very few studies have examined whether uniform policies are associated with number of students' problem behaviors while considering various school safety efforts. Various school safety programs contribute to reducing or preventing students' problem behaviors, and so uniform policies and other school safety initiatives should be examined simultaneously. By doing so, we can investigate the estimated effect of uniform policy as a school safety purpose (Brunsma \& Rockquemore, 1998; Stamison, 2006). For this reason, the current study included major school safety initiatives in the regression analysis, such as crime prevention programs for students (Wilson, Gottfredson, \& Najaka, 2001), teacher training programs focused on classroom management and safety policies (McManus, 1995; Raffaele Mendez et al., 2002), and parental involvement (Essex, 2001; U.S. Department of Education, 1996).

Second, unlike most studies that used the perception of school staff or students, the present study used official school records to assess number of students' problem behaviors. Number of students' problem behaviors reported by schools can be more accurate to examine the effect of uniform policies regardless of their opinion of the uniform policies.

Third, past studies indicated that school types are associated with the relationship between uniform policies and student outcomes (Brunsma $\&$ Rockquemore, 1998). In order to avoid the effects of uniform policies resulting from school types, the current study focused on public schools only. Finally, uniform policies are more common in urban areas, so this study focused on data obtained from urban schools.

This study examined the effects of school uniform policies as a school safety facilitator; the findings will provide initial evidence of the influence of uniform policies and help guide policy decision making. Specific research questions are: 1) How many schools adopt a mandatory school uniform policy in an urban area? 2) How do patterns of student's problem behaviors in schools with a uniform policy differ from schools without a uniform policy? 3) How is a uniform policy associated with students' problem behaviors when controlled for other school safety initiatives? 


\section{Method}

\section{Data}

The study is based on the nationally representative School Survey on Crime and Safety's (SSOCS) 200304 data. The SSOCS data survey has been administered by the National Center for Education Statistics (NCES) with support from the U.S. Department of Education every two years since the 1999-2000 academic year. The NCES developed the SSOCS questionnaire with assistance from a Technical Review Panel (TRP) comprising nationally recognized experts in the field such as school safety issues, school crime, and crime prevention practices. The questionnaire contains 227 items under eight sections. The eight sections include school practice and programs focused on school safety; parent and community involvement at school; teacher training; limitations in crime prevention; frequency of crime and violence at school; number of student problem behavior incidents; disciplinary problems and actions; and school characteristics. The survey questions were given as three types of choices: a dichotomous variable, such as yes or no; a categorical variable, such as selecting one of the given choices, like "limit in major way," "limit in minor way," and "does not limit;" and providing an actual number or percentage (Guerino, Hurwitz, Noonan, Kaffenberger, \& Chandler, 2006).

\section{Sampling}

The population of the SSOCS data includes all K-12 public schools in the United States. For the SSOCS 2003-04 data, participants were selected by a stratified sampling method from public schools (Guerino et al., 2006). The target population was divided by mutually exclusive groups or strata which were created by variables, such as school levels, school size, school location, percentage of minority students, and geographic region (Dinks, Cataldi, Lin-Kelly, \& Snyder, 2007). To obtain reliable results, the samples of the SSOCS data were allocated with different portions according to school levels rather than relying on proportional allocation (Guerino et al., 2006). In the study, schools that were located in a city and whose student body had more than 50 percent minority students were selected.
As a result, out of 2,772 samples, 421 urban schools were selected for the analysis.

\section{Measures}

Students' problem behaviors.

Principals were asked to report the number of offenses-use or possession of a firearm or explosive device; use or possession of a weapon other than a firearm; distribution, possession, or use of illegal drugs; distribution, possession, or use of alcohol; physical attacks or fights; insubordination; hate crimes; and gang-related incidents-that occurred at school during the 2003-04 school year. The sum of students' problem behaviors were included as an independent variable in the multiple regression models.

\section{Uniform policies.}

Principals were asked whether the school required students to wear uniforms during the 2003-04 school year, and they answered yes or no. In the analysis, this variable was recoded as yes $=1$ and no $=0$, and the variable refers to schools with a mandatory uniform policy.

\section{Parental involvement.}

Principals were asked whether their schools provide 1) a formal process for parental participation in school crime or discipline-related policies, 2) training or technical assistance to parents in dealing with student's problem behavior, and 3) a program of parents' help (at school) to maintain school discipline. Principals answered yes or no, and each item was recoded as yes $=1$ and no $=0$ for the analysis.

Crime prevention programs for students.

Principals were asked whether their school formally implemented violence prevention programs. Those items included 1) prevention curriculum, 2) behavior modification, 3) counseling, 4) individual tutoring, 5) recreation activities, 6) resolving student behavior problems, 7) programs to enhance sense of community, and 8) a hotline to report problems. Principals answered yes or no to each item, and those were recoded as yes $=1$ and no $=0$. 


\section{Teacher training programs.}

Principals were asked whether the school or district provided training programs for classroom teachers or aides in the following topics: 1) classroom management, 2) discipline policies and practices, 3) safety procedures, 4) recognizing early warning signs of violent behavior, 5) drug or alcohol problems, and 6) positive behavioral intervention strategies. Principals answered yes or no to each item, and each item was recoded as yes $=1$ and no $=0$.

\section{Community effort.}

This variable measured the involvement of outside community groups in the school's efforts to promote safe, disciplined, and drug-free schools. Principals answered yes or no about the involvement of given agencies, such as social service agencies, juvenile justice agencies, law enforcement agencies, mental health agencies, civic organizations and service clubs, private corporations and businesses, and religious organizations. All responses were recorded as yes $=1$ and no $=$ 0 , and a sum of the items was used in the study.

All school safety initiatives above were used as sums in the multiple regression analysis.

Additionally, the percentage of underachievers and school size-significant factors of students' problem behaviors-were included in the model. The percentage of underachievers was assessed by the percentage of students below the 15th percentile on standardized tests, and the number of enrolled students as of October 1, 2003, was used as school size.

\section{Statistical analysis}

Descriptive statistics, a one-way analysis of variance (ANOVA), and multiple regression analysis were conducted in the study (see Appendix A). Since some schools have a greater number of students' problem behaviors than others, the cases are distributed as a positively skewed pattern. For this reason, the variable was transformed using a base 10 logarithm in the multiple regression analysis. In the process of transforming, each case was added 1 because many cases have zero value. Weighted data was used to minimize problems resulting from differential probability of sampling.

\section{Results}

Table 1 reports the number and percentage of schools with and without a mandatory uniform policy. Approximately 34 percent of urban schools had adopted a mandatory uniform policy. More than 40 percent of elementary schools and middle schools (44.2 percent and 44.5 percent, respectively) had adopted uniform policies, whereas only 12 percent of high schools had uniform polices.

Table 1: Urban Schools Adopting a Mandatory School Uniform Policy

\begin{tabular}{lccccc}
\hline & All school levels & Elementary school & Middle school & High school & Combined school \\
\cline { 2 - 6 } & $\mathrm{n}(\%)$ & $\mathrm{n}(\%)$ & $\mathrm{n}(\%)$ & $\mathrm{n}(\%)$ & $\mathrm{n}(\%)$ \\
\hline Schools without & 277 & 72 & 86 & 116 & 3 \\
uniform policies & $(65.8)$ & $(55.8)$ & $(55.5)$ & $(87.9)$ & $(60.0)$ \\
Schools with & 144 & 57 & 69 & 16 & 2 \\
uniform policies & $(34.2)$ & $(44.2)$ & $(44.5)$ & $(12.1)$ & $(40.0)$ \\
\hline Total & $421(100.0)$ & $129(100.0)$ & $55(100.0)$ & $132(100.0)$ & $5(100.0)$ \\
\hline
\end{tabular}

Figure 1 (page 7) presents the ANOVA results for the comparison of students' problem behaviors between schools with and without a mandatory uniform policy. Schools with no uniform policies had more frequent students' problem behaviors than schools with uniform policies. In particular, the mean of firearm- related problems $(M=0.42$ vs. $0.13, p<.01)$ and drug-related problems $(M=6.72$ vs. $3.16, p<.05)$ was significantly higher in schools with no uniform policies than those of schools adopting uniform policies. 


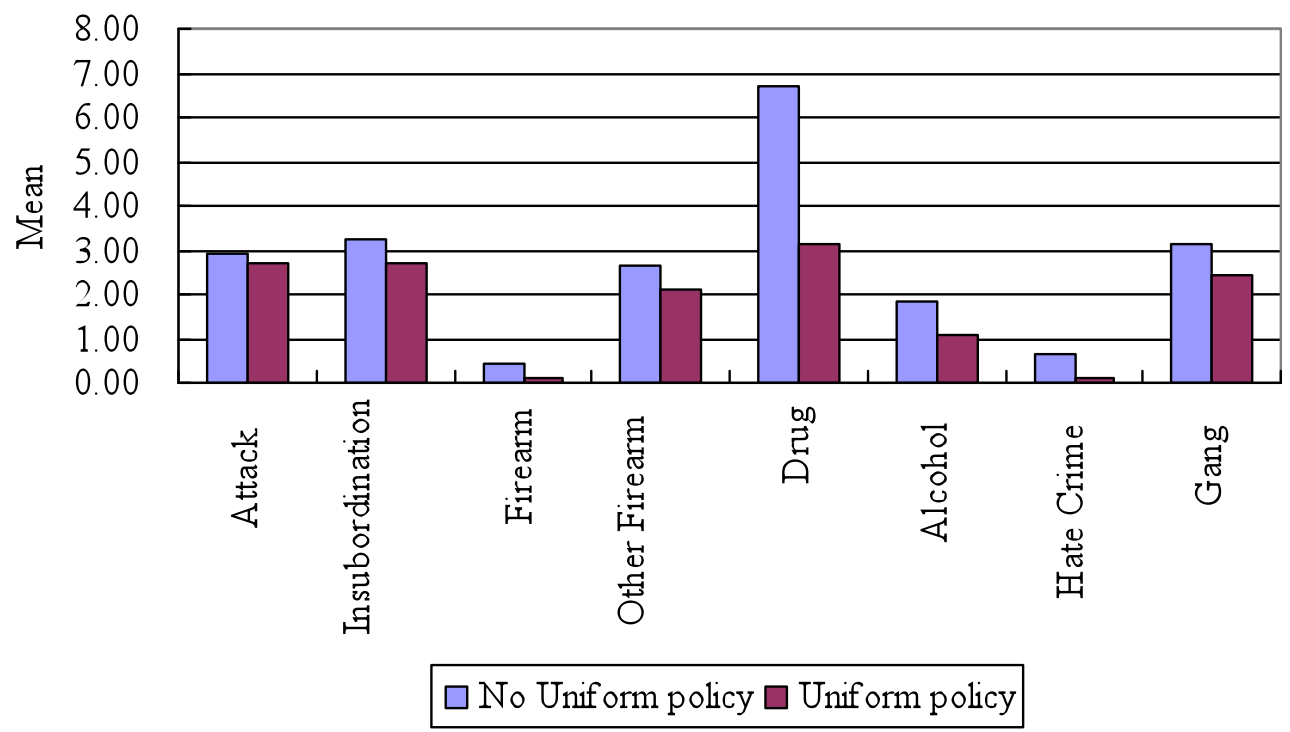

Figure 1: Comparison of Schools with a Mandatory School Uniform Policy and Schools without a Mandatory School Uniform Policy: Number of Students' Problem Behaviors

Figure 2 shows that the percentage of schools with at least one incident was compared between schools with and without uniform policies. More than half of schools without uniform policies (54.9 percent) had at least one weapon-related incident, whereas less than 40 percent of schools with uniform policies (38.9 percent) had at least one weapon-related incident. Fire- arm-related incidents (19.5 percent versus 7.6 percent), drug-related incidents (58.5 percent versus 43.1 percent), alcohol-related incidents (35.0 percent versus 16.7 percent), and gang problems (29.6 percent versus 20.1 percent) occurred in a greater number in schools without uniform policies than in schools adopting uniform policies.

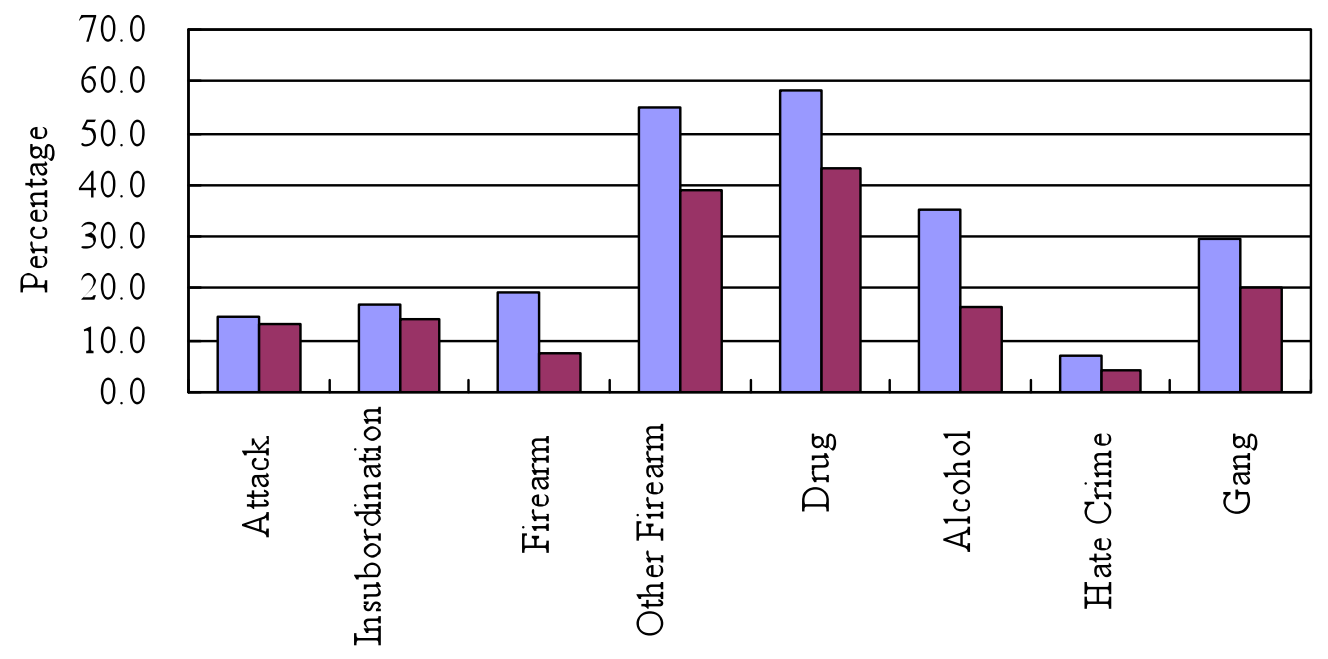

$\square$ No Uniform policy $\square$ Unif orm policy

Figure 2: Comparison between Schools with a Mandatory School Uniform Policy and Schools without a Mandatory School Uniform Policy: Percentage of Schools with one or more Incidents

Table 2 (page 8) presents coefficients for a mandatory uniform policy and students' problem behaviors ac- counting for school safety initiatives and school characteristics. Results of multiple regression analysis indi- 
cated that a mandatory school uniform policy significantly affects number of students' problem behaviors negatively. However, there were different patterns when data are analyzed by school levels. Although a uniform policy had significantly negative relationship with number of students' problem behaviors at the elementary school $(p<.001)$ and middle school levels $(p<.01)$, a significant positive relationship appeared at the high school level $(\mathrm{p}<.01)$.

Table 2: Effect of a Mandatory School Uniform Policy and Safety Initiatives on Students' Problem Behaviors

\begin{tabular}{lllll}
\hline & All schools & Elementary schools & Middle schools & High schools \\
\cline { 2 - 5 } Variable & Coefficient & Coefficient & Coefficient & Coefficient \\
& $(S E)$ & $(S E)$ & $(S E)$ & $(S E)$ \\
\hline Uniform policies & $-.208^{* * *}$ & $-.238^{* * *}$ & $\left(.066^{* *}\right.$ & $.104^{* *}$ \\
Student crime Prevention & $(.011)$ & $(.012)$ & $(.023)$ & $(.035)$ \\
programs & $(.007$ & -.004 & .007 & $.037^{* * *}$ \\
Teacher training & $.038^{* * *}$ & $(.005)$ & $(.009)$ & $(.010)$ \\
& $(.004)$ & $.037^{* * *}$ & .003 & $-.034^{* * *}$ \\
Parental Involvement & $-.091^{* * *}$ & $(.004)$ & $(.008)$ & $(.009)$ \\
& $(.006)$ & $\left(.068^{* * *}\right.$ & $.076^{* * *}$ & .010 \\
Community efforts & $.066^{* * *}$ & $.064^{* * *}$ & $(.014)$ & $(.012)$ \\
& $(.003)$ & $(.003)$ & .013 & $-.013^{*}$ \\
Percent of underachiever & $.003^{* * *}$ & $.002^{* * *}$ & $(.007)$ & $(.007)$ \\
& $(.000)$ & $(.000)$ & -.001 & .000 \\
School size & $.147^{* * *}$ & -.004 & $(.001)$ & $(.001)$ \\
\hline$N$ & $(.006)$ & $(.008)$ & $.239 * *$ & $.395^{* * *}$ \\
\hline$R^{2}$ & 421 & 129 & $(.014)$ & $(.014)$ \\
\hline$* p<.05, * * p<.01, * * * p<.001$ & .10 & 155 & 132 \\
\hline
\end{tabular}

Note: All schools include elementary, middle, high, and combined schools.

Other school safety efforts also showed negative relationships with number of students' problem behaviors. Parental involvement has a significant negative relationship on number of students' problem behaviors at the elementary school level $(p<.001)$. If schools provide opportunities for parents to get involved in the formal process of school safety and discipline policies, to get training or technical assistance to control students' problem behaviors, and to help students' discipline practices at school, then those schools are less likely to have students' problem behaviors. In addition, schools implementing multiple teacher training programs are less likely to have students' problem behaviors at the high school level $(p<.001)$.

However, the relationship was revealed as positive at the elementary school level. Implementing various crime prevention programs for students had no statistically significant relationship with the number of stu- dent problem behavior, but its significant positive relationship appeared at the high school level. Schoolcommunity cooperation for creating safe schools showed a significant negative relationship with number of students' problem behaviors at the high school level $(p<.05)$. Elementary schools with a greater percentage of underachievers $(p<.001)$ and middle and high schools with a larger student population $(p<$ .001) are more likely to have students' problem behaviors.

In sum, implementing a uniform policy does have a negative relationship with number of students' problem behaviors at the elementary and middle school levels but does not at the high school level, after controlling for other school safety initiatives and school characteristics. 


\section{Discussion}

The primary purpose of this study is to examine the estimated effect of a mandatory school uniform policy on number of students' problem behaviors. Analyzing samples from nationally representative data, the author finds that schools with uniform policies tend to have a negative relationship with number of students' problem behaviors after controlling other school safety initiatives, and these results are consistent with the literature (Hughes, 2006; Loesch, 1995; Lopez, 2003; White \& Beal, 1999). However, such relationships differ by school levels.

Elementary and middle schools with uniform policies tend to have fewer student problem behaviors than schools without uniform policies, whereas high schools adopting uniform policies are more likely to have frequent students' problem behaviors $(p<.01)$. Policymakers should reconsider adopting a uniform policy at the high school level. Different mediation of reinforcement (e.g., teacher-mediated or peer-mediated approaches) can be more effective in this age group than externally enforced school policies. Additionally, school practitioners should understand a developmental change as well when adopting uniform policies at the high school level.

Parental involvement is a significant negative predictor of students' problem behaviors at the elementary school level $(p<.001)$. Schools that encourage parental involvement in making decisions about school safety policies tend to have fewer student problem behaviors. It is important for school practitioners to be aware of the significant role of parents, in terms of their input and involvement in decision making, in school safety policies. However, the relationship was revealed as positive at the middle school level. Such inconsistent relationships should be examined in a more comprehensive way (e.g., whether parental involvement in making decision on school safety policies differs by school level).

Teacher training and community efforts are negatively associated with the number of students' problem behaviors at the high school level, whereas the associations are positive at the elementary school level. High school students are more likely to be involved in serious and various types of problem behaviors (e.g., weapon-related behaviors, drugs, and gang activities), compared to elementary or middle school students.
Multiple approaches, including teacher training and community agencies, are possibly more effective in preventing students' problem behaviors at the high school level than at the elementary and middle school levels. High school administrators should actively encourage community agencies to get involved in creating safe schools, and they should provide multiple crime-prevention training programs to teachers. In addition, previously addressed teacher training programs (e.g., drugs and alcohol-related prevention and violence prevention) may fit better at the high school level than at the elementary or middle school levels. Further studies on this issue should be focused on the nature and types of teacher training programs and community involvement according to the school level.

Although many researchers indicate that a mandatory uniform policy should not be adopted as an easy way to control students' problem behaviors or as a decisive means to create a safer school (Brunsma \& Rockquemore, 1998; Lumsden, 2001), the current study shows a negative relationship between a mandatory uniform policy and the number of students' problem behaviors in urban school settings. Thus, school uniform policies might be considered to prevent or reduce students' problem behaviors. However, it is worthy to note that uniform policies do have a significant positive relationship with students' problem behaviors at the high school level.

The present study has several limitations. First, the data analyzed in the study is cross-sectional data; the causality among variables cannot be determined. Second, measurement of various school safety practices and programs for students, parents, and teachers is limited; these were measured by whether schools implement these programs or not, which is a dichotomous variable. The data do not provide more detailed information about how often and how long they implement the programs, how those programs are administered, or the quality of the programs. In this regard, conducting qualitative studies is required to further explore this subject. Third, the sample size of high schools with uniform policies is small, and so the interpretation of the results should be approached cautiously. Finally, whether students agree to adopt school uniform policies (DaCosta, 2006; Hughes, 2006; Kim $\&$ Delong, 2006) is critical for obtaining positive outcomes. Student involvement in the decision-making process for adopting a mandatory uniform policy can 
influence the effectiveness of the policy (DaCosta, 2006). Unfortunately, data about this matter were not available.

Despite these limitations, the findings provide useful information about the differential effects of uniform policies on students' problem behaviors across school levels, and it should provide school administrators and policymakers in urban areas additional insight when they attempt to solve students' problem behaviors by adopting uniform policies.

\section{References}

Achilles, G. M., McLaughlin, M, J., \& Croninger, R. G., (2007). Sociocultural correlates of disciplinary exclusion among students with emotional, behavioral and learning disabilities in the SEELS national datasets. Journal of Emotional and Behavioral Disorder, 15(1), 33-45.

Anderson W. (2002). School dress codes and uniform policies. Retrieved from:

http://eric.ed.gov/ERICDocs/data/ericdocs2sql/cont ent_storage_01/0000019b/80/29/d2/92.pdf

Applied Research Center (2002). Profiled \& punished:

How San Diego schools undermine Latino \& African student achievement. Retrieved from http://www.eric.ed.gov/ERICDocs/data/ericdocs2sql /content_storage_01/0000019b/80/1a/ab/37.pdf

Arcia, E. (2007). A comparison of elementary/K-8 and middle schools' suspension rates. Urban Education, 42(5), 456-469.

Boutelle, M. (2008, February). Uniforms: Are they a good fit? Educational Digest, 73 (6), 34-37.

Brown, T. J. (1998). Legal issues and the trend towards school uniforms (ERIC Document Reproduction Service No. ED447588).

Brunsma, D. (2006, January/February). School uniform policies in public schools. Principal, 50-53.

Brunsma, D., \& Rockquemore, K. A. (1998). Effects of student uniforms on attendance, behavior problems, substance use, and academic achievement. The Journal of Educational Research, 92(1), 53-62.

Center for Disease Control and Prevention (2006). Youth risk behavior surveillance-United States, 2005. Washington, D.C.: Department of Health and Human Services. Retrieved from: http://www.cdc.gov/mmwr/PDF/SS/SS5505.pdf
DaCosta, K. (2006). Dress code blues: An exploration of urban students' reactions to a public high school uniform policy. The Journal of Negro Education, 75(1), 49-59.

Draa, V. A. B. (2005). School uniforms in urban public high schools. Unpublished doctoral dissertation, Youngstown State University. Retrieved from http://eric.ed.gov/ERICDocs/data/ericdocs2sql/cont ent_storage_01/0000019b/80/2b/61/36.pdf

Devine, J. (1996). Maximum Security: The culture of violence in inner-city schools. Chicago and London: The University of Chicago Press.

Dinks, R., Cataldi, E. F., Lin-Kelly, W., \& Snyder, T. D. (2007). Indicators of school crime and safety: 2007. Washington DC: U.S. Department of Education. Retrieved from: http://nces.ed.gov/pubs2008/2008021.pdf

Essex, N. L. (2001, January). School uniforms: Guidelines for principals. Principal, 38-39.

Fosseen, L. A. (2006). School uniforms in middle school: Enhancing identity and security. In D. L. Brunsma (Ed.). Uniforms in public schools: A decade of research and debate (pp.79-113). Lanham, MD: Rowman \& Littlefield Education.

Guerino, P., Hurwitz, M.D., Noonan, M.E., Kaffenberger, S. M., \& Chandler, K. (2006). Crime, violence, discipline, and safety in U.S. public schools: findings from the school survey on crime and safety: 2003-04. Washington, DC: U.S. Department of Education.

Hughes, E. (2006). Effects of mandated school uniforms on student attendance, discipline referrals, and classroom environment. In D. L. Brunsma (Ed.). Uniforms in public schools: A decade of research and debate (pp.51-77). Lanham, MD: Rowman \& Littlefield Education.

Irwin, D., \& Algozzine, B. (2005). North Carolina positive behavior support initiative evaluation report. Raleigh, NC: Department of Public Instruction, Exceptional Children Division, Behavioral Support Service. Retrieved from http://www.ncpublicschools.org/docs/positivebehav ior/data/evaluation/200304/ncevaluationreport0304.pdf 
Kim, Y. \& Delong, M. (2006). School dress codes and uniforms: Perspectives on wearing uniforms ion Korea and the United States. In D. L. Brunsma (Ed.). Uniforms in public schools: A decade of research and debate (pp.137-149). Lanham, MD: Rowman \& Littlefield Education.

Krezmien, M. P., Leone, P. E., \& Achilles, G. M. (2006). Suspension, race, and disability: Analysis of statewide practices and reporting. Journal of Emotional and Behavioral Disorders, 14(4), 217-226.

Lawrence, R. (2007). School crime and juvenile justice (2nd ed.). New York: Oxford University Press.

Loesch, P. C. (1995, March). A school uniform program that works. Principals, 74(4), 28.

Lopez, R. A. (2003). The Long Beach Unified school district uniform initiatives: A preventionintervention strategy for urban schools. The Journal of Negro Education, 72(4), 396-405.

Lumsden, L. (2001). Uniforms and dress-code policies. Child Development, 70, 1163-1180.

McManus, M. (1995). Troublesome behavior in the classroom: Meeting individual needs (2nd ed.). New York: Routledge.

Mellard, D., \& Seybert, L. (1996). Voices about school suspension, expulsion, and safety. Lawrence. KS: Center for Research on Learning. (ERIC Document Reproduction Service No. ED403639)

Pate, S. S. (2006). The influence of a mandatory school uniform policy in a rural and an urban school district. In D. L. Brunsma (Ed.). Uniforms in public schools: A decade of research and debate (pp. 3-11). Lanham, MD: Rowman \& Littlefield Education.

Portner, J. (1996). Uniforms get credit for decrease in discipline problems. Education Week, February 14, 2006. Retrieved from

http://www.edweek.org/ew/articles/1996/02/14/211 ong.h15.html

Raffaele Mendez, L. M., Knoff, H. M., \& Ferron, J. M. (2002). School demographic variables and out-ofschool suspension rates: A quantitative and qualitative analysis of a large, ethnically diverse school district. Psychology in the Schools, 39(3), 259277.
Raffaele Mendez, L. M., \& Knoff. H. M. (2003). Who gets suspended from school and why: A demographic analysis of schools and disciplinary infractions in a large school district. Education and Treatment of Children, 26 (1), 30-51.

Rausch, M. K., \& Skiba, R. (2004). Unplanned outcomes: Suspensions and expulsion in Indiana. Retrieved from

http://ceep.indiana.edu/projects/PDF/PB_V2N2_Un plannedOutcomes.pdf

Roberto, T., Lyttle, E., Morgan, J. G., Detch, E. R., Doss, P. E., \& Wright, D. (2006). Zero tolerance: An update 2006. TN: Offices of Research and Education Accountability. Retrieved from http://www.comptrollerl.state.tn.us/repository/RE/z erotol2006.pdf

Ryan, R. P., \& Ryan, T. E. (1998). School uniforms: Esprit de corps. The School Community Journal, 8(2), 81-84.

Stamison, V. (2006). The implementation and impact of mandatory school uniforms in Long Beach, California. In D. L. Brunsma (Ed.). Uniforms in public schools: A decade of research and debate (pp.151184). Lanham, MD: Rowman \& Littlefield Education.

Texas Education Agency (2007). Disciplinary alternative education program practices. Policy Research Report No. 17 (Document No. GE07 601 11). Austin, TX: Author. Retrieved from

http://www.tea.state.tx.us/research/pdfs/prr17.pdf

Thornberry, T. P., \& Krohn, M. D. (2000). The selfreport method for measuring delinquency and crime. Criminal Justice, 4, 33-83.

Thornton, C. H., \& Trent, W. (1988). School desegregation and suspension in East Baton Rouge Parish: A preliminary report. Journal of Negro Education, 57, 482-501.

U. S. Department of Education (1996). Manual on School Uniforms. Washington, DC: Office of Elementary and Secondary Education (ERIC Document Reproduction Service No. ED387947).

Wade, K. K., \& Stafford, M. E. (2003). Public school uniforms: Effect on perceptions of gang presence, school climate, and student self-perceptions. Education and Urban Society, 35(4), 399-420.

White, B. L., \& Beal, G. D. (1999). Violence in the schools as perceived by pre-service and in-service teachers. Contemporary Education, 71(1), 31-38. 
Wilson, D. B., Gottfredson, D. C., \& Najaka, S. S. (2001). School-based prevention of problem behaviors: A meta-analysis. Journal of Quantitative Criminology, 17(3), 247-272.

Zernike, K. (2002). Plaid's out, again, as schools give up requiring uniforms. The New York Times, September 13, 2002 Retrieved from http://query.nytimes.com/gst/fullpage.html?res=9A0 DE3DE1131F930A2575AC0A9649C8B63 


\section{Appendix A}

ANOVA results: Comparison of Number of Student Problem Behavior between School with and without a Mandatory Uniform Policy.

\begin{tabular}{lllllll}
\hline Measure & Having uniform policy & $\mathrm{N}$ & $\mathrm{M}$ & $\mathrm{SD}$ & $\mathrm{F}$ & $\mathrm{p}$ \\
\hline Attack & Uniform policy & 144 & 2.69 & 6.93 & .09 & .766 \\
& No Uniform policy & 277 & 2.90 & 7.10 & & \\
\hline Insubordination & Uniform policy & 144 & 2.69 & 6.74 & .58 & .447 \\
& No Uniform policy & 277 & 3.24 & 7.20 & & \\
\hline Firearm & Uniform policy & 144 & .13 & .50 & 8.84 & .003 \\
& No Uniform policy & 277 & .42 & 1.14 & & \\
\hline Other weapon & Uniform policy & 144 & 2.12 & 4.53 & 1.11 & .293 \\
& No Uniform policy & 277 & 2.66 & 5.30 & & \\
\hline Drug & Uniform policy & 144 & 3.16 & 6.06 & 5.11 & .024 \\
& No Uniform policy & 277 & 6.72 & 18.38 & & \\
\hline Alcohol & Uniform policy & 144 & 1.07 & 4.06 & 1.50 & .222 \\
& No Uniform policy & 277 & 1.81 & 6.67 & & .90 \\
\hline Hate crime & Uniform policy & 144 & .10 & .67 & .343 \\
& No Uniform policy & 277 & .68 & 7.19 & & .41 \\
\hline Gang & Uniform policy & 144 & 2.44 & 9.44 & .520 \\
& No Uniform policy & 277 & 3.14 & 11.15 & & \\
\hline
\end{tabular}

IJEPL is a joint publication of the Association for Supervision and Curriculum Development, the Faculty of Education at Simon Fraser University, and the College of Education and Human Development at George Mason University. By virtue of their appearance in this open access journal, articles are free to use, with proper attribution, in educational and other non-commercial settings 90 days after initial publication. Copyright for articles published in IJEPL is retained by the authors. More information is available on the IJEPL Web site: http://www.ijepl.org 